\title{
Pengelolahn Air Balas: \\ Kerangka Hukum Internasional dan Perbandingan HUKUM DI INDONESIA
}

\author{
Eliza Dayinta Harumanti ${ }^{1}$
}

\begin{abstract}
Abstrak
Pembuangan air balas kapal yang tidak diolah dan dibuang di sembarang tempat berpotensi menyebabkan perpindahan beberapa organisme laut yang tidak sesuai dengan lingkungan hidup awalnya. Organisme ini akan berkembang dan mengganggu sistem rantai makanan yang pada akhirnya berdampak pada pencemaran air laut dan keseimbangan ekosistem. Perhatian dunia internasional terhadap perlindungan laut terlihat dengan adanya konvensi yang mengatur tentang pembuangan air balas pada tahun 1992 sebagai upaya mitigasi untuk mencegah menyebarnya spesies predator serta untuk menjaga keseimbangan ekosistem di suatu daerah di dunia. Tulisan ini membahas perkembangan pengaturan pengelolaan air balas di dunia sampai dengan terbentuknya Konvensi Pengelolaan Air Balas dan perbandingan penerapannya di beberapa negara termasuk di Indonesia. Mengingat Indonesia belum meratifikasi ketentuan Konvensi Pengelolaan Air Balas, tulisan ini akan mengkaji kemungkinan Indonesia menjadi negara anggota konvensi tersebut.
\end{abstract}

Kata kunci: air balas, Indonesia, UNCLOS, invasive alien species

\section{Abstract}

This article attempts to discuss Indonesia's policy on ballast water exchange with regard to protection of the marine environment in Indonesia's water

\footnotetext{
${ }^{1}$ Asisten Peneliti pada Indonesian Center for Environmental Law (ICEL)
} 
territory. The exchange of ballast water is potential to inadvertently introduce non-native species into new habitat. These species are likely to thrive and harm the existing ecosystem, turning them to be invasive species. World's attention was gained after several disasters in some countries, calling the adoption of a new international standard as prevention and mitigation measures of such issue. This article will also address the development of Ballast Water Management Convention and compare other countries practice in their national law framework.

Keywords: ballast water, Indonesia, UNCLOS, invasive alien species

\section{Pengantar}

Sistem air balas adalah sistem yang sangat penting di dalam suatu kapal. Sistem air balas ini digunakan untuk menyeimbangkan kapal ketika kapal tidak membawa muatan sesuai dengan kapasitas maksimal mereka. Hal ini menjadi penting untuk menghadapi cuaca buruk ketika kapal berlayar di tengah samudera. ${ }^{2}$ International Maritime Organization atau Organisasi Maritim International ("IMO") mengartikan air balas sebagai "water with its suspended matter taken on board a ship to control trim, list, draught, stability or stresses of the ship."3

Banyaknya volume air yang dipompa masuk ke dalam tangki air balas bergantung pada besarnya ukuran kapal,4 yang mana pada umumnya akan mengisi $50 \%$ hingga $70 \%$ dari total kapasitas kapal. ${ }^{5}$

2 "Ballast Water", http:/www.epa.vic.gov.au/yourenvironment/water/ballast-water, diakses pada 20 Mei 2015.

3 "Ballast Water Management Convention," International Convention for the Control and Management of Ships' Ballast Water and Sediments, IMO Doc. BWM/CONF/36, 13 Februari 2004, art. 1(7).

${ }^{4}$ Penghitungan standar ukuran kapal menggunakan banyak satuan ukur. Satuan ukur yang sering sekali digunakan untuk mengukur kapasitas kapal kargo adalah Twenty-Foot Equivalent Unit (TEU) atau Forty-Foot Equivalent Unit (FEU). Sedangkan, berat kapal diukur dengan satuan Gross Tonnage (GT) Lihat: Michael Bohlman, "ISO's container standards are nothing but good news", ISO Bulletin, September 2001, hal. 12-15. Adapun ukuran kapal yang digunakan di dalam Ballast Water Convention adalah GT. Lih: "Ballast Water Management Convention, art.1(7).

${ }^{5}$ A. Whitman Miller, et.al, "Geographic Limitations and Regional Differences in Ships' Ballast Water Management to Reduce Marine Invasions in the Contiguous United States", BioScience vol. 61, 2011, hal. 881. 
Proses pemompaan dan pembuangan biasa terjadi di daerah pelabuhan ketika muatan kargo diturunkan atau dinaikkan. Proses ini mengandung banyak isu lingkungan, antara lain pembuangan air balas yang dikategorikan sebagai limbah karena sering mengandung minyak yang terkontaminasi, patogen berbahaya, dan proses pertukaran hewan laut yang berbeda habitat. ${ }^{6}$ Potensi pencemaran disebabkan kegiatan lalulintas perdagangan global melalui laut juga semakin meningkat seiring berjalannya waktu.

Dampak proses penggunaan air balas dalam kegiatan pelayaran kapal kargo yang paling mendapat perhatian adalah tereksposnya hewan non-endemik (non-native species) ke suatu lingkungan baru. Penelitian pertama mengenai hal ini dilakukan pada awal tahun 1900-an. Penelitian ini dilakukan di daerah North Sea dan melaporkan terdapatnya fitoplankton spesies Odontella (Biddulphia) sinensis yang merupakan jenis fitoplankton di perairan Asia. ${ }^{7}$

Dengan asumsi bahwa suatu tangki balas dapat menampung 3,4 juta ton air, sebanyak tujuh ribu spesies berbeda diestimasikan dapat berpindah tempat dalam satu kegiatan pelayaran kapal kargo. ${ }^{8}$ Berbagai penelitian telah membuktikan tentang banyaknya spesies dalam jumlah besar ditemukan dalam sampel air balas. Sebuah studi tentang proses shipping di Eropa menemukan bahwa ada seribu spesies yang dibawa di dalam air balas yang mencakup dari spesies satu sel seperti ganggang hingga berbagai spesies ikan. ${ }^{9}$

Perhatian serius mulai banyak ditunjukkan karena akibat ini tidak dapat diprediksi sebelumnya. Spesies flora dan fauna yang baru di suatu perairan tersebut dapat terus hidup dan menjadi dominan yang

${ }^{6}$ Simon C. Barry, et. al., "Ballast Water Risk Assessment: Principles, Processes, and Methods." ICES Journal of Marine Science 65, (2008), hal. 121.

${ }^{7}$ C.H. Ostenfeld, "On the Immigration of Bidulphia sinensis Grev. and its occurrence in the North Sea during 1903-1907", Meddelelser fra Kommissionen fo Havundersogelser, Plankton Vol 1 No. 6, 1908, hal 2.

${ }^{8}$ S.G. Bullard, et al., "Abundance and Diversity of Ascidians in the Southern Gulf of Chiriquí, Pacific Panama”, Aquatic Invasions Vol 6 No. 4, (2011), hal 381.

9 S. Gollasch, et al., "Life in Ballast Tanks" di dalam Invasive Aquatic Species of Europe: Distribution, Impacts and Management, ed. E. Leppakoski, et al., (Dordecht: Kluwer Academic Publishers, 2002), hal. 217-231. 
mengakibatkan ketidakseimbangan ekosistem. ${ }^{10}$ Dominasi flora dan fauna yang terbukti resisten karena tetap hidup di dalam tangki balas akan menginvasi spesies endemik di habitat barunya dalam perebutan makanan dan habitat. Dalam tingkat yang lebih serius, invasive alien species ("IAS") dapat mengubah kondisi lingkungan seperti mempengaruhi tingkat kejernihan air dan mengurangi keanekaragaman hayati lokal karena banyak spesies endemik yang tidak mampu bertahan hidup dengan invasi spesies baru di suatu habitat. ${ }^{11}$

Telah terjadi beberapa kasus yang mengindikasikan akibat buruk air balas di suatu lingkungan maritim. Pada tahun 1982, Mnemiopsis leidyi (American Atlantic Coast Comb Jelly) yang menjadi IAS di daerah Laut Hitam dan Laut Azov telah menyebabkan lingkungan di laut tersebut menjadi berbahaya dan beracun. Spesies tersebut menyebabkan meledaknya populasi ganggang dalam jumlah besar. Hal ini mengakibatkan berkurangnya kadar oksigen di sekitar Laut Hitam dan Laut Azov karena ganggang tersebut menutupi permukaan laut dan berbagai spesies rumput laut dan terumbu karang yang berfungsi untuk memproduksi oksigen. Ledakan populasi ganggang tersebut disebabkan oleh berkurangnya populasi zooplankton karena menjadi sumber makanan comb jelly. ${ }^{12}$

Dreissena polymorpha (zebra mussels) menginvasi habitat di Great Lakes, Kanada pada tahun 1988.Spesies ini juga membawa akibat buruk di Danau St. Clair, Detroit, Amerika Serikat pada tahun yang sama. Zebra mussels memiliki kemampuan untuk mengeliminasi berbagai mikroorganisme yang ada di perairan. Hal ini berakibat pada ketidakseimbangan rantai makanan, terutama untuk ikan-ikan tangkapan. Spesies ini terus berkembang biak dan menempel di kerang yang mengakibatkan kerang-kerang tersebut tidak bisa membuka cangkangnya untuk memperoleh nutrisi. Populasi kerang pun menurun

${ }^{10}$ Jenis flora dan fauna invasive ini dikenal dengan terminologi yang bermacam-macam, seperti alien invaders dan Invasive Alien Species (IAS). Untuk kepentingan penulisan artikel ini, terminology IAS akan digunakan untuk menghindari kebingungan di dalam pembahasan.

11 A.M. Ibrahim dan M.A. El-naggar, "Ballast water Review: Impacts, Treatments, and Management", Middle-East Journal of Scientific Research Vol 12 No. 17, (2012), hal. 976.

12 C. Bright, Life Out of Bounds: Bioinvasion in a Borderless World, Worldwatch Environmental Alert Series (New York, NY: Norton, 1998), hal. 182. 
drastis. Kerugian ekonomis yang besar juga dirasakan karena zebra mussels menghambat aliran air dan menyebabkan pembangkit listrik tidak berfungsi dan tutupnya beberapa pabrik. ${ }^{13}$

Australia juga pernah mengalami dampak negatif air balas. Perairan Australia terpapar ganggang Gymnodimium yang merupakan spesies endemik dari Jepang pada tahun 1998. Ganggang ini berkembang biak dengan sangat cepat dan menjadi racun bagi populasi shellfish di sekitar perairan negara bagian Tasmania. ${ }^{14}$

Melihat fenomena di atas, banyak negara dengan kapasitas maritim yang besar mulai menaruh perhatian mengenai dampak lingkungan akibat aktivitas pelayaran.Terdapat perkembangan pengaturan di mana air balas harus diolah sebelum akhirnya dilepaskan kembali ke alam. Perhatian ini ditindaklanjuti oleh IMO dengan membuat berbagai pedoman dan mekanisme pengaturan untuk mencegah kerusakan lingkungan dan ekosistem oleh IAS. Di dalam perkembangannya, terdapat tiga faktor yang mempengaruhi usaha IMO di dalam pencapaian tujuan dibentuknya berbagai regulasi, yaitu pembatasan jumlah konsentrasi makhluk hidup yang diperbolehkan di dalam air balas, penggunaan teknologi, serta kemauan dan kemampuan dari operator kapal untuk menggunakan teknologi tersebut dalam usaha untuk mematuhi ketentuan yang telah diatur. ${ }^{15}$

Indonesia tentunya juga memiliki potensi pencemaran air balas akibat kegiatan pelayaran yang sibuk di daerah perairannya. Salah satu contohnya adalah Selat Malaka yang menjadi perlintasan kapal paling sibuk di dunia. Dengan 2,33 milyar kapal yang singgah di Pelabuhan Singapura, ${ }^{16}$ perairan yang berbatasan langsung dengan Selat Malaka berpotensi mengalami pencemaran akibat air balas ini.

13 "Sea Ballast and Zebra Mussels (Ballast), http://www1.american.edu/ted/ballast.htm, diakses 22 Mei 2015; J. Ellen Marsden, "Zebra Mussel Study on Lake Michigan, Annual Report to Illinois Department of Conservation", Illinois Natural History Survey, Center for Aquatic Ecology, 1992, hal. 1.

14 G.C. Ray dan J. McCormick-Ray, "Coastal Marine Conservation: Science and Policy”, (UK: Blackwell, 2004), hal. 252.

${ }^{15}$ DM King, et.al. "Preview of Global Ballast Water Treatment", Journal of Marine Engineering and Technology, Vol 11, (2012), hal. 15.

${ }^{16}$ MPA: at the Helm of New Waves, Port View Singapore, 2Q/2014, https://www.singaporepsa.com/images/PortView/2014\%20PortViewQ2/HTML/f iles/assets/common/downloads/publication.pdf, diakses 22 Mei 2015. 
Tulisan ini membahas kepentingan Indonesia untuk meratifikasi Konvensi Air Balas. Selain membahas pengaturan dalam tingkat internasional dan nasional berbagai negara yang rentan terhadap dampak pencemaran air balas, tulisan ini juga akan menggunakan studi komparatif dalam membahas pengaturan nasional negara-negara yang pernah mengalami dampak air balas tersebut. Menyadari bahwa posisi Indonesia yang terletak di posisi silang menjadikannya sebagai jalur pelayaran yang paling sibuk berpotensi mengalami pencemaran air balas, ${ }^{17}$ maka tulisan ini juga akan mepaparkan pengaturan tingkat nasional yang sudah dimiliki oleh Indonesia dalam menanggulangi potensi pencemaran oleh air balas. Bagian kesimpulan tulisan ini akan menyimpulkan pembahasan serta menawarkan langkah-langkah mitigasi yang dapat dilakukan oleh pemerintah untuk melaksanakan perlindungan perairan yang rentan terhadap air balas.

\section{Kerangka Pengaturan Hukum Internasional mengenai Air Balas}

Di dalam hukum internasional, terdapat berbagai macam konvensi yang mengatur mengenai perlindungan lingkungan laut dari sumber pencemaran yang berasal dari kapal, antara lain air balas, minyak, atau sampah selama pelayaran. United Nations on the Law of the Sea (UNCLOS) mengatur mengenai perlindungan lingkungan laut di dalam Bagian XII. Terdapat enam sumber pencemaran terhadap lingkungan laut yang diatur di UNCLOS, yaitu aktivitas di daerah pantai, kegiatan pengeboran minyak di landas kontinen, penambangan di daerah seabed, pembuangan limbah ke laut (dumping), pencemaran yang berasal dari kapal, dan pencemaran dari lapisan atmosfir. ${ }^{18}$ Berdasarkan konsep ini, pembuangan air balas dapat dikategorikan sebagai pencemaran yang

17 United States Department of State, Bureau of Oceans and International Environmental and Scientific Affairs, "Limits in the Seas, No. 141, Indonesia: Archipelagic and other Maritime Claims and Boundaries", dirilis 15 September 2014, hal. 6.

${ }^{18}$ UNCLOS, "United Nations on the Law of the Sea", 1833 UNTS 3, art. 194. 
berasal dari kapal. ${ }^{19}$ UNCLOS mengatur mengenai kewajiban bagi negara peserta untuk menjaga dan melindungi lingkungan laut ${ }^{20}$ dengan cara melakukan serangkaian tindakan yang bertujuan untuk mencegah dan mengontrol pencemaran lingkungan laut. Tindakan ini dapat dilakukan dengan cara bekerjasama dengan negara peserta lain. ${ }^{21}$ Adapun negara memiliki kewajiban untuk membuat mekanisme hukum untuk menanggulangi pencemaran yang berasal dari kapal yang sesuai dengan standar internasional. ${ }^{22}$ Selain itu, berdasarkan mekanisme hukum ini negara peserta juga dapat memberlakukan hukumnya terhadap kapalkapal yang terbukti telah mempengaruhi kerusakan lingkungan akibat bahan pencemar yang dikeluarkannya. ${ }^{23}$ Namun, UNCLOS tidak mengatur mengenai standar implementasi kewajiban tersebut. ${ }^{24}$

Pada tahun 1973, IMO mengadopsi International Convention for the Prevention of Pollution from Ships ("Konvensi Marpol").25 Akibat minimnya jumlah ratifikasi, dibuatlah protokol pada tahun 1978 yang melengkapi ketentuan di dalam Konvensi Marpol 1973. Konvensi ini mulai berlaku sejak 2 Oktober 1983 dengan terpenuhinya ketentuan ratifikasi yang membutuhkan minimal 15 negara yang mewakili persentase shipping tonnage di dunia sebanyak lima puluh persen. ${ }^{26}$ Hingga saat ini, telah ada 162 negara yang meratifikasi Konvensi Marpol beserta enam Annex lainnya yang bersifat teknis. ${ }^{27}$

19 Daniel Bodansky, "Protecting the Marine Environment from VesselSource Pollution: UNCLOS III and Beyond", Ecology Law Quarterly Vol. 18 Issue 4, (1991), hal. 724-725.

${ }^{20}$ UNCLOS, Op. Cit., art. 192.

${ }^{21}$ Ibid., art. 194.

${ }^{22}$ Ibid., art. 211

${ }^{23}$ Ibid., art. 220.

${ }^{24}$ Myron H. Nordquist, et al. (ed), "United Nations Convention on the Law of the Sea, 1982: A Commentary, (1991), hal. 234.

${ }^{25}$ Konvensi ini lebih dikenal dengan nama Marpol (Marine Pollution). Terminologi Marpol akan digunakan selanjutnya di dalam pembahasan artikel ini.

${ }^{26}$ Marpol 73/78 Convention, "International Convention for the Prevention of Pollution from Ships", 1340 UNTS 61, art. 15.

27 Konvensi Marpol diamandemen pada tahun 1997 sedangkan Annex keenam mulai berlaku pada tahun 2005. [International Convention for the Prevention of Pollution from Ships (MARPOL), Sumber: http://www.imo.org/About/Conventions/ListOfConventions/Pages/InternationalConvention-for-the-Prevention-of-Pollution-from-Ships-(MARPOL).aspx, diakses pada 27 Mei 2015. 
Konvensi Marpol bertujuan melindungi lingkungan laut dengan cara mengeliminasi pencemaran akibat minyak dan bahan beracun lainnya serta mengurangi tumpahan bahan pencemar tersebut secara tidak sengaja. ${ }^{28}$ Konvensi ini mengatur mengenai tiga tipe umum sumber pencemaran yang berasal dari laut: (1) discharge standards, atau standar pembuangan, yang diatur dengan menentukan batas maksimal pembuangan minyak dan sampah yang diizinkan. Walaupun keluarnya bahan pencemar dari kapal dapat terjadi dengan tidak disengaja, namun pembuangan yang dimaksud ketentuan ini dilakukan dengan kesengajaan dalam suatu volume tertentu; (2) construction, design, equipment, and manning standards (CDEM standards), yang bertujuan untuk meningkatkan keamanan pelayaran untuk menghindari suatu kecelakaan yang menimbulkan pencemaran laut, memfasilitasi penerapan dan pengawasan standar pembuangan; (3) navigation standard, atau standar pelayaran, yang berkaitan dengan kegiatan pelayaran kapal. Seiring berjalannya waktu, standar pelayaran ini diimplementasikan dengan pembentukan traffic separation scheme, batas kecepatan, dan prosedur keselamatan umum.

Inisiatif pengaturan air balas secara internasional di dalam suatu konvensi tersendiri muncul setelah terjadi beberapa kasus pencemaran di berbagai negara di dunia. Sejak tahun 1993, telah terjadi diskusi di IMO untuk mencari cara dalam menghadapi akibat buruk ekologis air balas. Berbagai pedoman berhasil dibuat oleh IMO, yaitu Marine Environmental Protention Committee (MEPC) Resolution (50)31 (Guidelines for Preventing the Introduction of Unwanted Organism and Pathogens from ships' Ballast Water and Sediment Discharges); IMO Assembly Resolution A. 774 (18) (Guidelines for Preventing the Introduction of Unwanted Organism and Pathogens from Ships' Ballast Water and Sediment Discharges), ${ }^{29}$ dan IMO Resolution A. 868(20), (Guidelines for the Control and Management of Ships' Ballast Water to Minimise the Transfer of Harmful Organism and Pathogens)..$^{30}$ Pedoman-

${ }^{28}$ Marpol 73/78 Convention, art. 1.

${ }^{29}$ IMO Assembly Resolution A. 774 (18), Guidelines for Preventing the Introduction of Unwanted Organism and Pathogens from Ships' Ballast Water and Sediment Discharges, 4 November 1993, Sumber: http://www.sjofartsverket.se/upload/5121/774.pdf, diakses 29 Mei 2015.

30 IMO Resolution A. 868(20), Guidelines for the Control and Management of Ships' Ballast Water to Minimise the Transfer of Harmful Organism and Pathogens, 27 November 1997, Sumber: 
pedoman tersebut kemudian ditindaklanjuti oleh masing-masing negara dengan pembuatan standar dan prosedur dalam kegiatan pengambilan dan pembuangan air balas di zona teritorial. ${ }^{31}$

Berbagai pedoman di atas dibuat dengan usulan kepada negara berdasarkan prinsip precautionary approach. Negara diminta untuk mengidentifikasi wilayah teritorial yang memiliki kemungkinan menjadi tempat pembuangan air balas, melakukan usaha untuk memastikan bahwa air balas yang dikeluarkan bersih dari IAS, dan menentukan bahwa pengambilan air balas tidak dilakukan di daerah dangkal. ${ }^{32}$ Upaya mitigasi ini lebih banyak dibebankan kepada port state dibandingkan dengan flag state. Selain itu, terdapat pihak lain yang terlibat, sebagaimana tercantum di dalam tujuan "to assist Governments and appropriate authorities, ship masters, operators and owners, and port authorities, as well as other interested parties, in minimizing the risk of introducing harmful aquatic organism and pathogens from ships' ballast water and associated sediments while protecting ships safety."33

Pedoman tersebut tidak mampu menanggulangi peningkatan IAS di berbagai daerah baru yang tercemar. Berbagai negara pun menerapkan berbagai standar yang berbeda yang berlaku di dalam teritorialnya. Hal ini yang memaksa kebutuhan adanya suatu tatanan hukum baru yang mengatur mengenai standar internasional di dalam sebuah perjanjian internasional. ${ }^{34}$ Pada tahun 1999, dibentuk the Ballast Water Working Group of MEPC yang memulai penulisan rancangan perjanjian internasional yang khusus mengatur mengenai air balas. ${ }^{35}$ Terdapat pemikiran untuk menyertakan pengaturan ini sebagai annex baru dari Konvensi Marpol, tetapi berkembang pendapat bahwa perubahan ekologis lautan akibat IAS memiliki perbedaan dalam hal

${ }^{31}$ IMO Assembly Resolution A. 774 (18), guideline 4, par. 1; IMO Resolution A. 868(20), guideline 4 par. 3.

${ }^{32}$ IMO Assembly Resolution A. 774 (18), guideline 6, par. 1.

${ }^{33}$ IMO Resolution A. 868(20), guideline 4 par. 1.

${ }^{34}$ Sarah McGee, "Proposals for Ballast Water Regulations: Biosecurity in an Insecure World", Colorado Journal of International Environmental Law and Policy Vol 141, (2012), hal. 153.

35 Tony George Puthucherril, "Ballast Waters and Aquatic Invasive Species: A Model for India", Colorado Journal of International Environmental Law and Policy Vol 19, (2008), hal. 394. 
akibat serta mekanisme dan metode pencegah, mitigasi, dan penanganan dibandingkan dengan tumpahan minyak. ${ }^{36}$ Selain itu, penambahan pengaturan air balas sebagai annex akan mengakibatkan kurang kuatnya implementasi di dalam hukum nasional. ${ }^{37}$ Maka, pengaturan mengenai air balas ini dibuat di dalam rezim baru hukum internasional di dalam International Convention for the Control and Management of Ships' Ballast Water and Sediments ${ }^{38}$ atau Konvensi Pengendalian dan Pengelolaan Air Balas dan Sedimen Kapal ("Konvensi Air Balas”).

Konvensi Air Balas terdiri dari 22 pasal yang mengatur mengenai kewajiban flag states dan port states. Konvensi ini memiliki lima annex. Bagian A mengatur mengenai aturan umum (general provisions) yang menjelaskan berbagai terminologi yang digunakan di dalam konvensi. Bagian B mengatur mengenai ketentuan pengelolaan dan kontrol terhadap kapal. Setiap kapal diwajibkan untuk menerapkan konsep pengelolaan air balas. Konsep tersebut harus disetujui oleh pihak yang berwenang dan berisikan hal-hal minimum yang telah diatur oleh Konvensi Air Balas. ${ }^{39}$ Bagian C mengatur beberapa wilayah dengan aturan khusus. Hal ini berhubungan dengan ketentuan khusus yang harus dipenuhi oleh kapal untuk memenuhi persyaratan yang diatur oleh beberapa negara secara khusus. Persyaratan yang ditentukan oleh negara ini bersifat tambahan dan harus dikomunikasikan kepada IMO paling lambat 6 bulan sebelum penetapan aturan tersebut secara sah. ${ }^{40}$ Selain itu, negara yang akan memberlakukan peraturan tambahan harus berkonsultasi dengan negara lain yang akan terkena dampak serta menyesuaikan dengan ketentuan hukum internasional. Negara juga memiliki kewajiban untuk memberi notifikasi apabila perairan di suatu area tidak dapat menjadi tempat kegiatan pembuangan dan pengambilan air balas. ${ }^{41}$ Bagian D mengatur standar pengelolaan air balas, sedangkan Bagian E mengatur ketentuan tentang survei dan sertifikasi pengelolaan air balas. Di luar annex, konvensi ini memiliki 17 pedoman lain yang

${ }^{36}$ Hellen Foncesa de Souza Rolim, The International Law on Ballast Water: Preventing Biopollution, (Leiden, Boston: Martinus Nijhoff Publishers, 2008), hal. 53.

37 Moira McConnell, GloBallast Legislative Review: Final Report GloBallast Monograph, Series No. 1, (London:IMO, 2002), hal. 32.

${ }^{38}$ Selanjutnya akan disebut dengan BWM Convention.

${ }^{39}$ BWM Convention, Section B, Regulation B-1.

${ }^{40}$ Ibid, Section C, Regulation C-1.

${ }^{41}$ Ibid, Section C, Regulation C-2. 
tidak bersifat mengikat namun memberikan pedoman teknis mengenai implementasi Konvensi Air Balas.

Berdasarkan ketentuan di dalam Konvensi Air Balas, sebuah kapal harus membuang atau mengambil air balas paling tidak 200 mil laut dari pulau terdekat dan di perairan dengan kedalaman paling sedikit 200 meter. Jika hal ini tidak memungkinkan, praktik ini dilakukan sejauhjauhnya dari pulau tedekat atau paling sedikit sejauh 50 mil laut dari pulau terdekat dengan kedalaman perairan yang sama. ${ }^{42}$ Port states juga diberikan kewenangan untuk menentukan area khusus untuk kegiatan pengambilan atau pembuangan air balas dengan konsultasi dan kesepakatan dengan negara tetangga. ${ }^{43}$ Ketentuan yang terdapat di dalam Bagian B ini berkaitan dengan Bagian D karena kapal dengan mekanisme air balas diwajibkan untuk mempraktikkan pembuangan atau pengambilan air balas dengan prinsip efisiensi, yaitu paling tidak memenuhi $95 \%$ volume tangki. ${ }^{44}$ Selain itu, kapal wajib memastikan bahwa dalam satu meter kubik air balas yang dikeluarkan terkandung kurang dari sepuluh organisme hidup dan tidak melebihi indikator mikrobakteria yang ditentukan. ${ }^{45}$ Kapal juga wajib memenuhi standar teknologi pengolahan air balas dengan peninjauan dari IMO. 46

Hingga saat ini, Konvensi Air Balas telah memiliki 44 negara anggota yang mewakili $34,86 \%$ gross ton pelayaran dunia. ${ }^{47} \mathrm{Hal}$ ini belum memenuhi ketentuan ratifikasi untuk membuat Konvensi Air Balas menjadi berlaku karena ketentuan ratifikasi mensyaratkan negara peserta mewakili sekurang-kurangnya $35 \%$ gross ton pelayaran dunia. ${ }^{48}$ Hal yang perlu diperhatikan adalah bahwa justru negara-negara yang

${ }^{42}$ Ibid, Section B, Regulation B-4.

${ }^{43}$ Ibid.

${ }^{44}$ BWM Convention, Section D, Regulation D-1.

${ }^{45}$ Ibid, Section D, Regulation D-2.

${ }^{46}$ Ibid, Section D, Regulation D-4.-4

${ }^{47}$ IMO, "Status of multilateral Conventions and instruments in respect of which the International maritime organization or its Secretary-General performs depositary or other functions", 18 May 2015.

48 "This Convention shall enter into force twelve months after the date on which not less than thirty States, the combined merchant fleets of which constitute not less than thirty-five percent of the gross tonnage of the world's merchant shipping, have either signed it without reservation as to ratification, acceptance, or approval, or have deposited the requisite instrument of ratification, acceptance, approval or accession [...]" Lih: BWM Convention, art. 18 par. 1. 
mendominasi pelayaran dunia, seperti Panama, Singapura, Finlandia, dan Amerika Serikat, tidak meratifikasi Konvensi Air Balas.

\section{Praktik di Kanada dan Malaysia}

Penulis melakukan studi perbandingan dengan Kanada dan Malaysia dalam hal penerapan ketentuan pengelolaan air balas sesuai dengan Konvensi Air Balas di tingkat nasional. Kedua negara tersebut adalah negara anggota konvensi ini dan menjadi negara dengan praktik terdepan di tingkat regional.

Kanada menjadi negara anggota Konvensi Air Balas pada tanggal 8 April 2010. Namun, Kanada telah memulai untuk mengembangkan konsep ini sejak tahun 1980-an. Pada tahun 1989 Kanada mempublikasikan sebuah pedoman terkait pengelolaan air balas berdasarkan studi di Grande Entrée Lagoon, Magdalen Islands. Pedoman ini mensyaratkan kapal yang masuk ke daerah perairan St. Lawrence River dan Great Lakes dari luar zona ekonomi eksklusif Kanada untuk melakukan pembuangan air balas dan kemudian mengambil kembali di tengah samudera atau di zona tertentu yang telah ditentukan berdasarkan kedalaman dan tingkat salinitas. ${ }^{49} \mathrm{Hal}$ ini didukung pembuatan peraturan serupa oleh Amerika Serikat pada tahun 1993 karena wilayah Great Lakes berada di kedua negara.50 Sejak saat itu, pengaturan air balas di wilayah Great Lakes dan St. Lawrence merupakan pengaturan yang paling ketat di dunia. ${ }^{51}$ Pedoman ini menjadi sumber pembuatan pedoman oleh IMO. ${ }^{52}$

Pedoman yang dibuat Kanada ini dibuat ke dalam suatu undangundang pada tahun 2006 dengan nama Ballast Water Control and Management Regulations (selanjutnya disebut dengan Canada Ballast

49 Transport Canada, "Discussion Paper: Canadian Implementation of the Ballast Water Convention”, 26 Oktober 2012, hal. 5.

${ }^{50}$ United States Ballast Water Regulations,

http://el.erdc.usace.army.mil/zebra/zmis/zmishelp/united_states_ballast_ water_regulations.htm, diakses 1 Juni 2015.

${ }^{-}{ }^{51}$ The Great Lakes Seaway Ballast Water Working Group, "2013 Summary of Great Lakes Seaway Ballast Water Working Group February 2014”, hal. 2.

\footnotetext{
${ }^{52}$ Transport Canada, op. cit.
} 
Water Regulation) ${ }^{53}$ sebagaimana diamanatkan oleh Canada Shipping Act. ${ }^{54}$ Undang-Undang ini mewajibkan setiap kapal berbendera Kanada serta semua kapal yang akan masuk ke dalam yurisdiksi Kanada untuk melakukan proses pengelolaan air sebagai berikut,

"Ballast water is managed if one or more of the following management processes are employed: (a) the ballast water is exchanged; (b) the ballast water is treated; (c) the ballast water or any sediment that has settled out of it in the vessel's tanks is transferred to a reception facility; and 9d) the ballast water is retained on board the vessel." 55

Canada Ballast Water Regulation ini mengatur hal yang tidak berbeda dengan Konvensi Air Balas. Konvensi tersebut juga mengatur bahwa ketentuan tentang sistem air balas tidak berlaku bagi kapal yang hanya beroprasi di dalam wilayah teritorial Kanada. Kanada membedakan pengaturan bagi kapal-kapal domestik tersebut dengan pertimbangan ilmiah dari Fisheries and Oceans Canada sebagai otoritas pemerintah yang memiliki lingkup kewenangan untuk mengatur kegiatan perikanan domestik. ${ }^{56}$

Undang-undang ini juga mengatur mengenai 95\% total volume air balas yang dibuang atau diambil 57 serta pembahasan kandungan organisme yang terdapat di dalam air balas setelah diolah dan siap dibuang.58 Selain itu, kapal diwajibkan untuk membawa rencana pengelolaan air balas ketika berlayar. ${ }^{59}$ Dalam rencana pengelolaan ini, terdapat deskripsi tentang proses pengelolaan air balas, prosedur awak kapal dalam pengelolaan air balas, prosedur keselamatan awak kapal, prosedur pembuangan endapan hasil pencucian secara rutin tank air balas, prosedur koordinasi dengan pihak otoritas Kanada, spesifikasi

${ }^{53}$ Canada, Ballast Water Control and Management Regulations, 2006, SOR/2011-237.

${ }^{54}$ Canada, Canada Shipping Act, 2001, S.C. 20001, c. 26.

${ }^{55}$ Canada, Ballast Water Control ad Management Regulations, Pasal 4 ayat (1).

${ }^{56}$ Transport Canada, loc. cit., hal. 7.

${ }^{57}$ Canada, Ballast Water Control and Management Regulations, Pasal 8.

${ }^{58}$ Ibid, Pasal 9.

${ }^{59}$ Ibid,Pasal 11 ayat (1). 
sistem air balas masing-masing kapal, serta prosedur koordinasi dengan otoritas Kanada yang telah ditempuh. ${ }^{60}$

Pada tahun 2013, semua kapal yang masuk ke daerah Great Lakes dari luar zona ekonomi eksklusif Kanada menempuh pemeriksaan pengelolaan air balas pada saat kapal tersebut transit. Jumlah kapal yang diinspeksi mencapai 6803 tank air balas dari 371 kapal. Kapal yang tidak mengikuti prosedur yang telah diatur Canada Ballast Water Regulation diharuskan untuk tetap membawa air balas dan residunya karena tidak diperbolehkan untuk mengganti di daerah Great Lakes, mengolah air balas di wilayah lain yang aman bagi lingkungan, atau kembali ke laut untuk melakukan pembuangan dan kembali dengan air balas yang diambil dari wilayah 200 mil dari garis pantai Kanada. Proses verifikasi ini membuktikan bahwa tidak air balas yang dibuang di daerah Great Lakes yang tidak memenuhi prosedur. Di tahun itu, semua kapal yang masuk ke Great Lakes Seaway tidak dilengkapi dengan sistem pengelolaan air balas. ${ }^{61}$ Namun, sistem inspeksi dan verifikasi ini terbukti efektif karena berhasil mencegah masuknya IAS ke dalam ekosistem Great Lakes sejak tahun 2006. ${ }^{62}$

Malaysia meratifikasi Konvensi Air Balas pada tanggal 27 September 2010 dan menjadi negara anggota pertama, dan satu-satunya hingga saat ini, di Asia Tenggara. Di dalam instrumen ratifikasinya, Malaysia menyatakan bahwa ketentuan Konvensi Air Balas baru berlaku secara efektif di Malaysia pada tahun 2011.63 Namun, Pemerintah Malaysia menunda implementasi Konvensi Air Balas hingga waktu yang tidak ditentukan. ${ }^{64}$ Selain itu, Malaysia tidak memiliki undang-undang khusus tentang manajamen air balas sebagaimana Kanada.

Pada tanggal 15 Maret 2012, Jabatan Laut Malaysia sebagai otoritas yang berwenang mengeluarkan notifikasi kepada pemilik kapal, agen perkapalan, nakhkoda, pelaut, operator pelabuhan, dan pengusaha di

${ }^{60}$ Ibid, Pasal 11(2).

${ }^{61}$ The Great Lakes Seaway Ballast Water Working Group, loc. Cit.

${ }^{62}$ S.A. Bailey, et.al., "Evaluating Efficacy Of An Environmental Policy to Prevent Biological Invasions", Environmental Science and Technology Vol. 45, (2011), 2554-2561.

${ }^{63}$ Malaysia, Implementation of Internaitonal Convention for the Control and Mangement of Ships' Ballast Water and Sediments, 2004 (BWM Convention), MSN 28/2011.

${ }^{64}$ Jabatan Laut Malaysia, Installation of Ballast Water Treatment System, MSN 04/2012, angka 2. 
bidang kepelabuhanan dan industri maritim untuk menyesuaikan dengan instalasi sistem pengelolaan air balas. Kapal yang mulai dibuat setelah 1 Juni 2012 dengan kapasitas air balas sebesar 5000 meter kubik harus melaksanakan Regulasi D-2 Konvensi Air Balas, yaitu ketentuan batas mikroorganisme yang terkandung di dalam air balas yang akan dibuang. ${ }^{65}$ Hal ini berlaku bagi kapal yang berasal dari luar zona ekonomi eksklusif Malaysia yang akan memasuki pelabuhan Malaysia. ${ }^{66}$ Ketentuan ini tetap berlaku meskipun pelaksanaan Konvensi Air Balas belum berlaku efektif di Malaysia.

\section{Praktik di Indonesia}

Indonesia belum meratifikasi Konvensi Air Balas meskipun merupakan salah satu negara yang diproyeksikan sebagai negara anggota Konvensi Air Balas. Hal ini disebabkan kegiatan pelayaran di Indonesia yang cukup sibuk, memenuhi persentase 4,15\% yang disyaratkan oleh Konvensi Air Balas. ${ }^{67}$ Indonesia dikabarkan telah menunjukkan kemauan yang kuat untuk meratifikasi Konvensi Air Balas. 68

Dengan lalu lintas kapal yang padat di Selat Malaka, perairan Indonesia ditengarai rawan terhadap pencemaran yang disebabkan air balas. ${ }^{69}$ Meskipun hampir semua wilayah perairan Indonesia dilewati kapal-kapal sebagai konsekuensi sebuah negara kepulauan, tingkat pelanggaran di dalam aktivitas pembuangan air balas di wilayah jalur

${ }^{65}$ Ibid. angka 1.

${ }^{66}$ Installation of Ballast Water management System for the Ships Calling at Malysian Ports, http://www.ombros-consulting.com/?p=1164, diakses tanggal 1 Juni 2015.

${ }^{67}$ DM King, et.al, loc. cit., hal. 6.

${ }^{68}$ More Countries Get Behind Ballast Water Convention, Sumber: http://www.tradewindsnews.com/weekly/347257/More-countries-get-behindballast-water-convention, diakses 1 Juni 2015.

69 Pencemaran Air Ballast Ancam Perairan Batam, http://kepri.antaranews.com/berita/28809/pencemaran-air-ballast-ancamperairan-batam, diakses 1 Juni 2015. 
pelayaran Samudera Hindia yang juga melewati Indonesia dikategorikan rendah. ${ }^{70}$

Walaupun Indonesia belum meratifikasi Konvensi Air Balas namun pengaturan tentang pengelolaan sistem air balas telah diatur didalam Peraturan Menteri Perhubungan Nomor 29 Tahun 2014 tentang Pencegahan Pencemaran Lingkungan Maritim (selanjutnya disebut "PM 29/2014"). Patut digarisbawahi bahwa tujuan diberlakukannya peraturan ini mengacu pada tujuan Konvensi Marpol, yaitu mencegah pencemaran laut akibat tumpahan minyak. ${ }^{71}$ Padahal, Konvensi Air Balas bertujuan untuk mencegah pencemaran laut akibat IAS yang memerlukan mekanisme berbeda di dalam pengaturannya.

PM 29/2014 mengatur mengenai pengelolaan air balas hanya dalam 3 pasal yaitu pasal 48, pasal 49, dan pasal 50. Namun, di dalam pasal lainnya peraturan ini juga mengatur bahwa kapal tangki minyak ukuran 100 GT sampai dengan 149 GT wajib membawa oil record book yang mencatat berbagai kegiatan, salah satunya adalah pengisian air balas, pembuangan balas kotor, serta pengisian dan pembuangan tangki balas pada tangki muatan dan pada tangki balas bersih. ${ }^{72}$ Sedangkan untuk kapal yang difungsikan mengangkut muatan bahan cair beracun secara curah wajib menyediakan cargo record book untuk mencatat aktivitas yang sama. ${ }^{73}$ Selain itu diatur juga mengenai pembuangan kotoran (sewage) yang harus dilakukan pada jarak minimal 12 mil, atau 3 mil apabila sewage telah melalui alat pengolah atau alat penghancur kotoran, dari garis pantai terdekat. ${ }^{74}$

Pasal 48 PM 29/2014 menyatakan bahwa setiap kapal dengan ukuran 400 GT atau lebih yang membawa air balas dan berlayar di perairan internasional wajib memenuhi ketentuan Konvensi Air Balas. Hal ini menegaskan bahwa ketentuan Konvensi Air Balas tidak berlaku di dalam wilayah teritorial Indonesia.Terlebih di dalam Pasal 48 ayat 2

${ }^{70}$ A.W. Miller, et. al, Status and Trends of Ballast Water Mangement in the United States, Third Biennal Report of the national Ballast Information Clearinghouse, Submitted to the United States Coast Guard, 2007, hal. 18.

71 Indonesia, PM 29 Tahun 2014, Peraturan Menteri Perhubungan Republik Indonesia tentang Pencegahan Pencemaran Lingkungan Maritim, Berita Negara Nomor 1115 Tahun 2014, Pasal 1 ayat (2).

${ }^{72}$ Ibid, Pasal 10 huruf h.

${ }^{73}$ Ibid, Pasal 17(a).

${ }^{74}$ Ibid, Pasal 27. 
PM 29/2014 dinyatakan bahwa peraturan ini harus dipenuhi oleh kapal yang membawa air balas dengan kapasitas 1500 meter kubik atau lebih yang berlayar di perairan Indonesia.

PM 29/2014 mewajibkan kapal yang diatur di dalam Pasal 48 ayat (2) tersebut untuk membawa ballast water record book dan rencana pengelolaan air balas yang disahkan pejabat yang berwenang. Selain itu, kapal dengan kapasitas air balas 1500 meter kubik hingga 5000 meter kubik atau lebih diwajibkan untuk menerapkan pengelolaan air balas. Pertukaran air balas yang diperbolehkan adalah hingga 95\% volume balas dengan jarak minimal pembuangan 25 mil laut dari daratan terdekat. ${ }^{75}$

Proses pengolahan air balas diwajibkan bagi kapal yang tidak membuang air balas pada jarak yang telah ditentukan di atas. Selain itu, diatur pula jumlah maksimum kandungn organisme dengan ukuran dan ketentuan yang sama sebagaimana diatur di dalam Konvensi Air Balas. ${ }^{76}$ PM 29/2014 juga mengatur klasifikasi kapal yang dibebaskan dari ketentuan pengelolaan air balas, yaitu kapal yang hanya beroperasi di area pelabuhan atau hanya berlayar tidak lebih dari 50 mil serta kapal yang digunakan sebagai unit penampungan terapung yang tidak berpindah. ${ }^{77}$

Meskipun tidak komprehensif, ketentuan yang telah diatur di Indonesia mengenai pengelolaan air balas telah mengindikasikan adanya perhatian terhadap upaya pencegahan masuknya IAS ke dalam perairan Indonesia. Selain itu, dengan pendekatan untuk memasukkan ruang lingkup pengaturan pengelolaan air balas ke dalam konsep pencegahan pencemaran laut oleh minyak tidak serta-merta membuat usaha pencegahan tersebut menjadi kurang efektif dengan berbagai pertimbangan berdasarkan segi kesiapan teknis.

\section{Potensi Ratifikasi Konvesi Air Balas oleh Indonesia}

Fakta bahwa beberapa bagian perairan Indonesia digunakan sebagai jalur pelayaran internasional dapat menjadi suatu ancaman

${ }^{75}$ Ibid, Pasal 49.

${ }^{76}$ Ketentuan ini sama dengan Regulation D BWM Convention.

${ }^{77}$ Indonesia, PM 29 Tahun 2014, loc. cit., Pasal 50. 
terjadinya pencemaran lingkungan akibat IAS. Adapun daerah pelayaran Indonesia yang sibuk terjadi di sekitar Selat Malaka dan daerah Alur Laut Kepulauan Indonesia ("ALKI") I yang mencakup alur pelayaran dari Laut Tiongkok Selatan ke Samudera Hindia atau sebaliknya, melintasi Laut Natuna, Selat Karimata, Laut Jawa, dan Selat Sunda. ${ }^{78}$ Hingga saat ini, belum terdapat laporan yang menyatakan adanya pencemaran akibat IAS di perairan Indonesia. Namun, berdasarkan prinsip precautionary principle, maka Indonesia perlu menyadari kepentingannya untuk melindungi wilayah laut dengan meratifikasi Konvensi Air Balas.

Hal yang perlu diantisipasi lebih jauh adalah kesiapan Indonesia untuk menyesuaikan dengan ketentuan Konvensi Air Balas apabila konvensi ini memenuhi syarat ratifikasinya. Hal ini merupakan konsekuensi dari perumusan Pasal 211 ayat (2) UNCLOS yang berbunyi sebagai berikut.

"States shall adopt laws and regulations for the prevention, reduction and control of pollution of the marine environment from vessels flying their flag or of their registry. Such laws and regulations shall at least have the same effect as that of generally accepted international rules and standards established through the competent international organization or general diplomatic conference."79

Indonesia perlu membuat pengaturan yang lebih spesifik mengenai visi pencegahan IAS berkembang biak dan mencemari wilayah perairan Indonesia. Perlu disadari bahwa PM 29/2014 memberikan kesan bahwa penyebab pencemaran air laut adalah akibat pencemaran minyak. Maka dari itu, adanya pengaturan yang terpisah dengan PM 29/2014 diperlukan untuk memberikan perhatian khusus mengenai ancaman kerusakan ekosistem akibat berubahnya sistem rantai makanan akibat invasive alien species.

Pembuatan tatanan baru peraturan mengenai pencegahan dampak air balas ini dapat dimulai dengan meratifikasi Konvensi Air Balas.

78 Indonesia, PP Nomor 37 Tahun 2002, Peraturan Pemerintah tentang Hak dan Kewajiban Kapal dan Pesawat Udara Asing dalam Melaksanakan Hak Lintas Alur Laut Kepulauan Melalui Alur Laut Kepulauan yang Ditetapkan, LN No 71 Tahun 2002, TLN No. 4210.

${ }^{79}$ UNCLOS, art.211 (2). 
Dengan menunjukkan keinginannya untuk terikat dengan pengaturan di dalam konvensi tersebut, Indonesia dapat dengan leluasa untuk mengadopsi ketentuan di dalam Konvensi Air Balas. Pengaturan yang terdapat di dalam konvensi ini sangat bersifat teknis, sehingga norma pengaturan yang dibutuhkan cukup setingkat peraturan menteri.

Peraturan baru ini perlu mengatur secara berbeda kapal berbendera Indonesia dan berbendera asing. Perlu juga diatur mengenai pembuangan air balas yang dilakukan kapal berbendera Indonesia karena terdapat kemungkinan kapal-kapal dalam negeri mengancam lingkungan maritim dengan adanya kekosongan hukum ini.

Selain itu, hal yang juga luput untuk diatur di dalam pengaturan mengenai pencegahan pencemaran lingkungan laut adalah tidak menyertakan Kementerian Lingkungan Hidup sebagai pihak yang terlibat dalam sistem koordinasinya. Dengan mengambil contoh pengaturan di dalam PM 29/2014, hanya Direktorat Jenderal Perhubungan Laut (Dirjen Hubla) Kementerian Perhubungan yang mendapatkan otoritas untuk melaksanakan fungsi pengawasan teknis terhadap pelaksanaan peraturan. Hal ini sebenarnya sesuai dengan misi Dirjen Hubla untuk menyelenggarakan perlindungan lingkungan maritim di perairan nusantara. ${ }^{80}$ Peran Kementerian Lingkungan Hidup akan sangat dibutuhkan apabila Indonesia ingin mengatur perlindungan lingkungan maritime secara komprehensif, termasuk upaya mitigasi pencemaran akibat pertukaran air balas jika diindikasikan telah terjadi.

\section{Kesimpulan}

Dalam sepuluh tahun sejak diadopsinya Konvensi Air Balas, konvensi ini belum juga berlaku karena belum memenuhi jumlah minimal ratifikasi negara di dunia. Mengingat bahwa ancaman mengenai IAS ini nyata dan sudah terjadi, maka perlu adanya perhatian khusus dari negara-negara lain yang berpotensi mengalami pencemaran, salah satunya Indonesia.

${ }^{80}$ Sumber: http://hubla.dephub.go.id/profil/Pages/Visi-Misi.aspx, diakses pada tanggal 25 Juli 2015. 
PM 29/2014 bisa menjadi langkah awal untuk menanggapi kebutuhan sebuah negara dalam melindungi lingkungan maritimnya. Hal yang luput untuk untuk diatur adalah bagaimana pembedaan pengaturan mengenai pengelolaan air balas bagi kapal yang berbendera Indonesia dan kapal asing. Tidak dinyatakan dengan jelas mengenai kewajiban yang harus dipenuhi bagi kapal berbendera Indonesia, padahal kapal-kapal dalam negeri juga mungkin mengancam lingkungan maritim dengan adanya kekosongan hukum ini.

Jika Konvensi Air Balas berlaku di masa mendatang, negaranegara di dunia akan memiliki kewajiban untuk meyesuaikan hukumnya dengan ketentuan Konvensi Air Balas. Hal ini disebabkan oleh berlakunya Konvensi Air Balas menandakan bahwa konvensi ini memenuhi syarat generally accepted international rules and standards. Hal ini yang harus diantisipasi oleh Indonesia dengan merumuskan ketentuan yang mengakomodasi kepentingn nasional. Selama tidak meratifikasi konvensi, maka ketentuan yang dibuat Indonesia tidak harus mengikuti standar yang diatur Konvensi Air Balas.

Bagaimanapun juga, keberhasilan Konvensi Air Balas ditentukan semata-mata oleh kemampuan para pemilik kapal untuk menyesuaikan dengan ketentuan yang telah diatur. Selain itu, hal yang akan menjadi perhatian lebih lanjut adalah bagaimana proses pengawasan dan pendeteksian ketidaksesuaian ketentuan sistem pengelolaan air balas. Perlu ada diskusi lebih jauh mengenai kemungkinan revisi ketentuan di dalam konvensi serta adanya asistensi finansial bagi negara dan bagi perusahaan kapal jika ingin menjadi aggota dari Konvensi Air Balas.

\section{Daftar Pustaka}

Bailey, S.A. et.al."Evaluating Efficacy Of An Environmental Policy to Prevent Biological Invasions", Environmental Science and Technology Vol. 45. (2011).

Ballast Water Treatment Market Remains Buoyant, http://www.waterworld.com/articles/wwi/print/volume-25/issue-

1/regulars/creative-finance/ballast-water-treatment-market-remainsbuoyant.html, diakses 1 Juni 2015.

Ballast Water, http://www.epa.vic.gov.au/your-environment/water/ballastwater, diakses pada 20 Mei 2015. 
Barry, Simon C., et. al., "Ballast Water Risk Assessment: Principles, Processes, and Methods." ICES Journal of Marine Science 65, (2008).

Bodansky, Daniel. "Protecting the Marine Environment from VesselSource Pollution: UNCLOS III and Beyond" Ecology Law Quarterly Vol. 18 Issue 4. (1991).

Bohlman, Michael. "ISO's container standards are nothing but good news", ISO Bulletin. 2001.

Bright, C. Life Out of Bounds: Bioinvasion in a Borderless World. Worldwatch Environmental Alert Series, New York. NY: Norton. 1998.

Bullard, S.G. et al. "Abundance and Diversity of Ascidians in the Southern Gulf of Chiriquí, Pacific Panama" Aquatic Invasions Vol 6 No. 4.(2011).

Canada. Ballast Water Control and Management Regulations (2006)

Canada. Canada Shipping Act (2001)

Gollasch, S, et al. "Life in Ballast Tanks" di dalam Invasive Aquatic Species of Europe: Distribution, Impacts and Management, ed. E. Leppakoski, et al. Dordecht: Kluwer Academic Publishers. 2002.

Ibrahim, A.M. dan M.A. El-naggar, "Ballast water Review: Impacts, Treatments, and Management", Middle-East Journal of Scientific Research Vol 12 No. 17. (2012).

IMO Assembly Resolution A. 774 (18), Guidelines for Preventing the Introduction of Unwanted Organism and Pathogens from Ships' Ballast Water and Sediment Discharges, 4 November 1993, http://www.sjofartsverket.se/upload/5121/774.pdf, diakses 29 Mei 2015.

IMO Assembly Resolution A. 774 (18). (1993)

IMO Resolution A. 868(20), Guidelines for the Control and Management of Ships' Ballast Water to Minimise the Transfer of Harmful Organism and Pathogens, 27 November 1997, http://globallast.imo.org/wpcontent/uploads/2015/01/Resolution-A.868_20_english.pdf, diakses 29 Mei 2015.

Indonesia, PM 29 Tahun 2014, Peraturan Menteri Perhubungan Republik Indonesia tentang Pencegahan Pencemaran Lingkungan Maritim, Berita Negara Nomor 1115 Tahun 2014. 
Installation of Ballast Water management System for the Ships Calling at Malaysian Ports, http://www.ombros-consulting.com/?p=1164, diakses tanggal 1 Juni 2015.

International Convention for the Prevention of Pollution from Ships (MARPOL)

International Maritime Organization."International Convention for the Control and Management of Ships' Ballast Water and Sediments." (2004).

International Maritime Organization. "International Convention for the Prevention of Pollution from Ships." (1973)

International Maritime Organization.Status Of Multilateral Conventions And Instruments In Respect Of Which The International Maritime Organization Or Its Secretary-General Performs Depositary Or Other Functions. 2015.

King, DM, et.al. "Preview of Global Ballast Water Treatment" Journal of Marine Engineering and Technology Vol 11. (2012).

Malaysia. Implementation of International Convention for the Control and Management of Ships' Ballast Water and Sediments, 2004 (BWM Convention) (2011)

Malaysia. Installation of Ballast Water Treatment System (2012)

Marsden, J. Ellen. Zebra Mussel Study on Lake Michigan, Annual Report to Illinois Department of Conservation", Illinois Natural History Survey, Center for Aquatic Ecology. 1992.

McConnell, Moira. GloBallast Legislative Review: Final Report GloBallast Monograph, Series No. 1. London: IMO. 2002.

McGee, Sarah. "Proposals for Ballast Water Regulations: Biosecurity in an Insecure World", Colorado Journal of International Environmental Law and Policy Vol 141. (2012).

Miller, A. Whitman, et.al. "Geographic Limitations and Regional Differences in Ships' Ballast Water Management to Reduce Marine Invasions in the Contiguous United States" BioScience vol. 61. (2011).

Miller, A.W. et. Al. Status and Trends of Ballast Water Management in the United States, Third Biennal Report of the national Ballast 
Information Clearinghouse, Submitted to the United States Coast Guard. 2007.

More Countries get behind ballast water convention, http://www.tradewindsnews.com/weekly/347257/More-countries-getbehind-ballast-water-convention, diakses 1 Juni 2015.

MPA: at the Helm of New Waves, Port View Singapore, 2Q/2014, https://www.singaporepsa.com/images/PortView/2014\%20PortViewQ2/ HTML/files/assets/common/downloads/publication.pdf, diakses 22 Mei 2015.

Nordquist, Myron H., et al. Ed. United Nations Convention on the Law of the Sea, 1982: A Commentary. 1991.

Ostenfeld, C.H. "On the Immigration of Bidulphia sinensis Grev. and its Occurrence in the North Sea during 1903-1907" Meddelelser fra Kommissionen fo Havundersogelser, Plankton Vol 1 No. 6. (1908).

Pencemaran Air Ballast Ancam Perairan Batam, http://kepri.antaranews.com/berita/28809/pencemaran-air-ballast-ancamperairan-batam, diakses 1 Juni 2015.

Puthucherril, Tony George. "Ballast Waters and Aquatic Invasive Species: A Model for India" Colorado Journal of International Environmental Law and Policy Vol 19, (2008).

Ray, G.C. dan J. McCormick-Ray, Coastal Marine Conservation: Science and Policy. UK: Blackwell. 2004.

Rolim, Hellen Foncesa de Souza. The International Law on Ballast Water: Preventing Biopollution. Leiden, Boston: Martinus Nijhoff Publishers. 2008.

Sea Ballast and Zebra Mussels (Ballast), http://www1.american.edu/ted/ballast.htm, diakses 22 Mei 2015.

Sinking Under A Big Green Wave, Sumber: http://www.economist.com/ news/business/21574517-shipowners-face-onslaught-new-environmentallaws-sinking-under-big-green-wave, diakses 1 Juni 2015.

The Great Lakes Seaway Ballast Water Working Group.2013 Summary of Great Lakes Seaway Ballast Water Working Group. 2014.

Transport Canada. Discussion Paper: Canadian Implementation of the Ballast Water Convention. 2012. 
United Nations General Assembly. "United Nations on the Law of the Sea." (1982)

United States Ballast Water Regulations,

http://el.erdc.usace.army.mil/zebra/zmis/zmishelp/united_states_ballast_water_r egulations.htm, diakses 1 Juni 2015.

http://www.imo.org/About/Conventions/ListOfConventions/Pages/International -Convention-for-the-Prevention-of-Pollution-from-Ships-(MARPOL).aspx, diakses 27 Mei 2015. 